\title{
ORANG INDIA DI PERKEBUNAN TEMBAKAU DELI: NARASI FOTO, 1872-1900
}

\author{
Apriani Harahap \\ Jurusan Pendidikan Sejarah, Universitas Negeri Medan, Indonesia \\ Email: aprianaiharahap@unimed.ac.id
}

\begin{abstract}
This article aims to look at the realities of Indian life in Deli tobacco plantations throughout 1872-1900. By using a research method that combines the historical study of East Sumatra plantation communities with the study of Indian coolies photos in the area taken from the Digital Collections Leiden University Libraries website, the reality of Indian coolies' life has never been written by Indonesian historians. The daily reality of Indians captured in photographs is the everyday side of working in Deli tobacco plantations. Differentiation of work, appearance, and settlement based on race is a picture of their lives while living on plantations. While working on plantations, Indian coolies earned an inadequate wage and had to bear the tremendous burden of life. Through photo narration, it can be understood how the reality of daily life of Indians in East Sumatra, which is currently a marginalized group in Indonesian history textbooks.
\end{abstract}

Keywords: Deli, Indian, Photo Narration, Tobacco Plantation

\begin{abstract}
Abstrak
Artikel ini bertujuan untuk melihat realitas kehidupan orang India di perkebunan tembakau Deli sepanjang tahun 1872-1900. Dengan menggunakan metode penelitian yang menggabungkan kajian sejarah masyarakat perkebunan Sumatera Timur dengan kajian foto-foto kuli India di daerah tersebut yang diambil dari website Digital Collections Leiden University Libraries akan terungkap realitas kehidupan kuli India yang sampai saat ini belum pernah ditulis oleh para sejarawan Indonesia. Realitas keseharian orang India yang terekam dalam foto merupakan sisi keseharian selama bekerja di perkebunan tembakau Deli. Diferensiasi pekerjaan, penampilan dan pemukiman berdasarkan ras merupakan gambaran kehidupan mereka saat hidup di perkebunan. Selama bekerja di perkebunan, kuli-kuli India memperoleh upah yang tidak layak dan harus menanggung beban hidup yang sangat luar biasa. Melalui narasi foto dapat dipahami bagaimana realitas kehidupan sehari-hari orang India di Sumatera Timur yang saat ini merupakan kelompok yang terpinggirkan dalam buku teks sejarah Indonesia.
\end{abstract}

Kata Kunci: Deli, Orang India, Narasi Foto, Perkebunan Tembakau 


\section{PENDAHULUAN}

Kajian sejarah tentang orang India di Indonesia belum begitu diminati kalangan akademik dibandingkan dengan kajian sejarah orang China. Gambaran kehidupan orang India di Indonesia justru lebih mudah ditemukan dalam kajian ilmiah yang dilakukan oleh sosiolog, antropolog dan arkeolog. Kajian sosiologi mengenai kehidupan orang India terdapat pada artikel yang ditulis A. Mani, seorang sosiolog dari Institute of Southeast Asian Studies Singapura, dengan judul Indians in North Sumatra (Mani, 1993: 46-97). Artikel yang ditulis oleh antropolog Zulkifli B. Lubis dengan judul Kajian Awal Tentang Koтиnitas Tamil dan Punjabi di Medan: Adaptasi dan Jaringan Sosial (Lubis, 2005: 136-146) dan Bambang Budi Utomo dari Balai Arkeologi Nasional yang mengkaji tentang pengaruh kebudayaan India dalam bentuk arca di Sumatera (Utomo, 2016: 35-60).

Kajian sejarah yang membahas tentang sejarah orang India adalah buku Tengku Luckman Sinar yang berjudul Orang India di Sumatera Utara (Sinar, 2008). Buku ini merupakan kajian pertama yang membahas sejarah orang India, meskipun lebih mirip kronik yang menjelaskan urutan-urutan setiap peristiwa yang dialami orang India mulai sejak awal abad ke-3 sampai abad ke-20. Namun kajian ini memberi tambahan informasi mengenai hubungan masyarakat India dengan masyarakat di pantai barat dan pantai timur Sumatera pada abad ke-3 Masehi, upacara perkawinan dan ritual keagamaan yang dilakukan orang Tamil dan Sikh di Sumatera Utara.

Dari kajian-kajian di atas dapat dikatakan bahwa studi ilmiah mengenai sejarah orang India di perkebunan tembakau Deli masih sangat langka. Oleh karenanya, artikel ini mencoba menghadirkan realitas masa lalu dari kehidupan sehari-hari orang India di Perkebunan Deli melalui narasi foto.

Berbicara mengenai kedatangan orang India di Indonesia sebagai pedagang tercatat pertama kali di awal milenium pertama, yakni ketika terjadi rute maritim melalui Selat Malaka dengan proses adanya perdagangan rempahrempah (Indradjaja, 2014: 180). Selain itu, kedatangan orang India ke kepulauan Indonesia sangat mungkin dalam upaya mencari emas (Coedes, 2010: 19). Seperti pada abad ke-7, pedagang India Tamil sudah melakukan perdagangan di wilayah Sumatera, tepatnya melakukan perniagaan dengan Kerajaan Sriwijaya yang menguasai bandar perniagaan di Selat Melaka. Jual-beli atau tukar menukar barang dagangan di Kerajaan Sriwijaya merupakan aktivitas perniagaan orang India pada saat itu. Kerajaan Sriwijaya juga mengenakan bea cukai yang cukup tinggi terhadap pedagang-pedagang India. Menurut Utomo (2016: 53-54), karena cukai yang dikutip kerajaan Śrīwijaya terlampau tinggi mengakibatkan Kerajaan Cōla dari India mengambil tindakan dengan menyerang Sriwijaya untuk melindungi para saudagar India. Setelah serangan Kerajaan Cōla tahun 1025, Kerajaan Śrīwijaya tidak lagi menguasai Selat Melaka seperti pada tahun-tahun sebelumnya.

Pada abad ke-11 sampai 14 Masehi, para pedagang India Selatan yang tergabung dalam serikat dagang Ayyavole Ainnurruvar atau Manikiram telah melakukan aktivitas di Situs Kota Cina, sebuah wilayah yang terletak di Kecamatan Medan Marelan, kota Medan. Hal ini dibuktikan dengan ditemukannya arca khas India Selatan yang membuktikan bahwa orang India telah tinggal secara permanen di Situs Kota Cina sepuluh abad yang lalu (McKinnon, 1984). Bahkan dalam Hikayat Deli dikemukakan bahwa pendiri Kesultanan Deli, Gocah Pahlawan, adalah keturunan seorang raja India (Sinar, 2006: 49). Namun berdasarkan sebuah laporan, keberadaan orang India sebagai ordinary people yang menetap di Deli dalam jumlah besar baru dimulai sejak empat dekade terakhir abad ke-19, ketika para pemodal swasta Barat mengeksploitasi hutan-hutan tropis Deli menjadi perkebunan-perkebunan tembakau. Seperti halnya orang Cina dan Jawa, orang India dikerahkan ke Deli untuk dipekerjakan sebagai kuli 
perkebunan, meskipun beberapa orang India datang ke perkebunan secara bebas atau tanpa menjadi kuli, seperti orang Sikh dan orang Bombay (Harahap, 2014: 26).

Di lingkungan perkebunan tembakau Deli, orang India hidup sebagai kuli yang dikontrol oleh pihak perkebunan. Berbagai kisah kehidupan, pekerjaan dan penampilan kuli India di perkebunan tembakau Deli sepanjang tahun 1872-1900 akan diungkap melalui narasi foto yang didapat dari website Digital Collections Leiden University Libraries. Taylor (2008: 315) mengemukakan foto dapat membantu memahami masa lalu, ide realitas dan ide kebenaran dalam peristiwa sejarah, meskipun terkandung motif tertentu pada saat proses pengambilannya. Demikian pula dengan foto-foto kuli India yang dikoleksi Digital Collections Leiden University Libraries dapat membantu kita memahami masa lalu mereka selama hidup di lingkungan perkebunan tembakau Deli. Meskipun foto-foto yang terdapat dalam website Digital Collections Leiden University Libraries menampilkan sudut pandang kolonial, tetapi narasi yang dibangun dari foto-foto itu bisa memberikan alternatif baru bagi penulisan sejarah orang India yang masih langka dalam historiografi Indonesia.

\section{METODE PENELITIAN}

Upaya untuk menarasikan orang India di perkebunan tembakau Deli dari tahun 1872 sampai 1900 didahului dengan heuristik. Sumber sejarah yang digunakan adalah foto yang diambil dari website Digital Collections Leiden University Libraries. Selama dalam pencarian di website tersebut ditemukan 54 foto tentang orang India di perkebunan Deli yang dimulai pada tahun 1872 sampai 1925. Namun foto yang diambil hanya pada akhir abad ke-19, tepatnya pada tahun 1872-1900. Pada saat mengunduh, fotofoto diberi judul, kode dan tahun. Foto dikelompokkan berdasarkan tema yang menarik, yakni kehidupan sehari-hari kuli India di saat bekerja di perkebunan, profil atau gaya penampilan mereka yang pada dasarnya merupakan foto-foto kaum terjajah yang diambil oleh penjajah (Taylor, 2008: 316-317). Melalui narasi foto ini akan dijelaskan dan ditafsirkan seperti apakah orang India yang menjadi masyarakat perkebunan di Ssumatera Timur.

Metode artikel ini sama dengan metode yang digunakan dalam kajian Taylor (2008: 313372), yakni menggabungkan kajian sejarah masyarakat perkebunan Sumatera Timur dengan kajian foto-foto kuli India di daerah tersebut yang diambil di website Digital Collections Leiden University Libraries. Foto-foto yang diunduh diperiksa dengan teliti, diuraikan secara ringkas dengan prinsip kronologis dan kausalitas. Dengan metode ini diharapkan akan memberikan pemahaman terhadap realitas masa lalu kehidupan orang India di perkebunan tembakau Deli tahun 1872-1900.

\section{HASIL DAN PEMBAHASAN}

\section{Perkembangan Perkebunan Tembakau Deli}

Tahun 1863, seorang pemodal swasta Barat bernama Jacobus Neinhus datang ke Deli dan memulai usaha perkebunan tembakau. Dalam beberapa kali uji coba, penanaman tersebut belum menuai hasil yang memuaskan, meskipun panen pertamanya menghasilkan daun yang berkualitas tinggi. Delapan tahun kemudian, akhirnya Neinhuys menuai hasil panen daun tembakau yang berkualitas tinggi dengan harga jual yang menguntungkan berkat bantuan modal dari Amsterdam yang didapatkannya untuk menanam tembakau Deli (Blink, 1918: 94).

Prospek perkebunan tembakau Deli yang dikembangkan oleh Nienhuys berkembang pesat dan membuat perusahaan Belanda, yakni Nederlandsche Handel Maatschappij (NHM) yang diwakili oleh Cremer, ikut andil dalam mendirikan perusahaan Deli Maatschappij pada akhir tahun 1869 dengan investasi modal yang besar. Terbukti dengan modal yang besar itu Deli Maatschappij mampu memiliki konsensus tanah seluas 10.000 bouw untuk menanam tembakau Deli (Lekkerkerker, 1916: 251). Perkembangan Deli Maatschappij dan mudahnya memperoleh 
hak konsesi dengan harga sewa yang rendah telah mendorong para pengusaha swasta Barat terus memperluas lahan perkebunan tembakau di Deli. Jumlah perkebunan tembakau mencapai 153 perkebunan, jauh meningkat dibandingkan dengan jumlah perkebunan pada tahun 1874.

Pesatnya peningkatan jumlah perkebunan tembakau di akhir abad ke-19 telah mendorong peningkatan jumlah produksi tembakau Deli. Pada periode 1872-1891, jumlah produksi tembakau meningkat tiga puluh lima kali lipat, dari 6.409 pak menjadi 225.629 pak (Harahap, 2014: 35). Jumlah produksi tembakau yang meningkat tajam pada akhir abad ke-19 memberikan keuntungan luar biasa bagi tuan kebun. Namun, peningkatan produksi juga berimbas terhadap bertambahnya jumlah tenaga kerja untuk memproduksi tembakau. Awalnya para tuan kebun mencari tenaga kerja dari penduduk lokal, namun kenyataannya penduduk lokal tidak mau bekerja dengan pengusaha perkebunan Eropa dikarenakan mereka sudah memiliki lahan atau mata pencaharian tersendiri, yakni berladang dan bertani. Alhasil, kelangkaan tenaga kerja mendorong pengusaha perkebunan mencari tenaga kerja dari luar daerah. Tenaga kerja yang pertama kali di rekrut tuan-tuan kebun Eropa adalah tenaga kerja dari Cina, baru menyusul tenaga kerja dari India dan Jawa (Breman, 1997: 23-68).

\section{Rekrutmen Kuli India}

Masalah terberat pengusaha Barat dalam memproduksi tembakau Deli adalah langkahnya tenaga kerja. Masalah ini sudah dialami Nienhuys sejak memulai usaha di Deli. Ketidakmauan penduduk lokal - orang Melayu dan Karo - direkrut menjadi buruh perkebunan menyebabkan Nienhuys mengerahkan 120 orang Cina dari Penang (Broersma, 1919: 33). Pengerahan jumlah kuli Cina terus berlanjut secara besar-besaran sampai akhir abad ke-19. Namun, saat biaya transportasi untuk merekrut kuli Cina menjadi mahal, tuan kebun beralih mencari tenaga kerja dari India dan Jawa.
Pada tahun 1883, jumlah kuli kontrak dari India di perkebunan tembakau Deli mencapai 1.528 orang. Jumlah itu meningkat menjadi 3.360 orang di tahun 1898 (Harahap, 2014: 2). Menurut laporan J.T. Cremer, kepala administratur Deli Maatschappij, kuli India yang bekerja di perkebunan adalah orang Tamil yang berasal dari pantai Koromandel di India Selatan. Mereka diidentifikasikan dengan sebutan Klings atau Klingalezeen (orang Keling) (Cremer, 1885: 301-311). Kuli-kuli Tamil direkrut dari Straits Settelements. Mereka didatangkan melalui $\mathrm{ka}$ ngany (broker kuli) dan perantara agen tenaga kerja. Sesampainya di Sumatera Timur, kuli India diwajibkan menandatangani kontrak kerja tanpa mengetahui isinya (Harahap, 2014: 40-41).

Berbagai permasalahan yang terjadi di India Selatan seperti kepadatan penduduk, kemiskinan dan krisis pangan menjadi faktor penyebab orang Tamil memutuskan untuk bermigrasi. Pada tahun 1871, pemerintah BritishIndia mengeluarkan kebijakan untuk mengatasi permasalahan kepadatan penduduk, kemiskinan dan krisis pangan yang menimpa India Selatan. Kebijakan ini dikemas dalam bentuk UndangUndang Emigrasi yang mengatur pengerahan tenaga kerja dari India. Selain itu, emigrasi orang India juga didorong oleh kebutuhan perkebunan di wilayah koloni Inggris lainnya akan tenaga kerja. Ceylon dan Straits Settlement merupakan tempat penduduk India Selatan dikerahkan menjadi buruh perkebunan. Dari Straits Settlements inilah orang-orang Tamil dikerahkan ke Sumatera Timur. Pengerahan orang Tamil ke Sumatera Timur untuk dipekerjakan sebagai kuli perkebunan sebenarnya dilarang pemerintah British-India, tetapi dikarenakan larangan emigrasi di Straits Settlements longgar, pengusaha perkebunan Sumatera Timur akhirnya dapat merekrut orang-orang Tamil dalam jumlah besar (Mani, 1993: 267).

Orang Tamil bermigrasi ke Sumatera Timur dengan harapan dapat memperbaiki kondisi sosial-ekonomi mereka, karena daerah asal mereka tidak mampu memenuhi kebutuhan 
hidup warganya. Di Sumatera Timur, mereka hidup di lingkungan perkebunan tembakau yang dikontrol oleh tuan-tuan kebun Eropa. Berikut akan dijelaskan kehidupan yang dialami orangorang Tamil selama bekerja di perkebunan Deli dalam bentuk narasi foto.

\section{Kuli India dalam Narasi Foto}

Perkebunan tembakau Deli pada akhir abad ke19 telah menciptakan komunitas perkebunan yang hetorogen dengan menunjukkan adanya pemisahan berdasarkan ras dan status sosial. Dalam hierarki kerja misalnya, staf-staf Eropa menempati lapisan teratas, kemudian orang Indis dan Asia terpelajar sebagai pegawai non-staf, selanjutnya pengawas-pengawas kuli (tandil dan mandor), dan terakhir kuli-kuli kontrak yang menjadi lapisan terbawah (Harahap, 2014: 49). Orang Eropa menduduki pekerjaan sebagai kepala administratur, administratur dan asisten (Stoler, 2005: 46). Kuli Cina kebanyakan dipekerjakan sebagai kuli ladang, mulai dari menyiapkan lahan, menanam dan merawat pohon tembakau sampai memanen daun tembakau. Kuli Jawa ditempakan dalam posisi menyiapkan lahan dan penanaman tembakau.

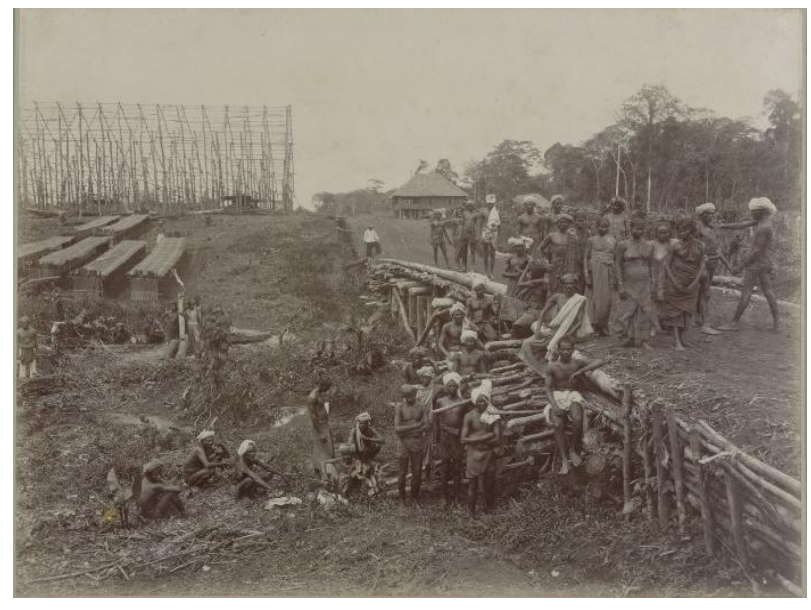

Foto 1. Kuli Tamil sedang membangun jalan dan jembatan di salah satu perkebunan tembakau Sumatera Timur pada tahun 1890. Sumber: Digital Collections Leiden University Libraries. Nomor Inv. 89988.
Sementara itu, kuli Tamil khusus dipekerjakan untuk membangun jalan, menggali kanal dan kusir gerobak sapi (pedati). Foto 1 dengan jelas memperlihatkan kuli-kuli Tamil sedang membangun jalan dan jembatan pada tahun 1890.

Mengenai pekerjaan membangun jalan dan kanal, kuli Tamil membangun infrastrukturinfrastruktur tersebut di tengah timbunan akar, dahan dan pohon-pohon mati yang sudah ditebas. Sepanjang hari tubuh mereka basah kuyup atau setengah basah, dikerubuti oleh pacet dan nyamuk (Cate, 1905). Dengan kondisi kerja seperti itu tentunya nyamuk malaria setiap saat mengancam jiwa kuli-kuli Tamil. Kondisi kerja yang berat dan tidak sehat yang harus dialami kuli-kuli Tamil terekam dalam foto 2 dan 3.

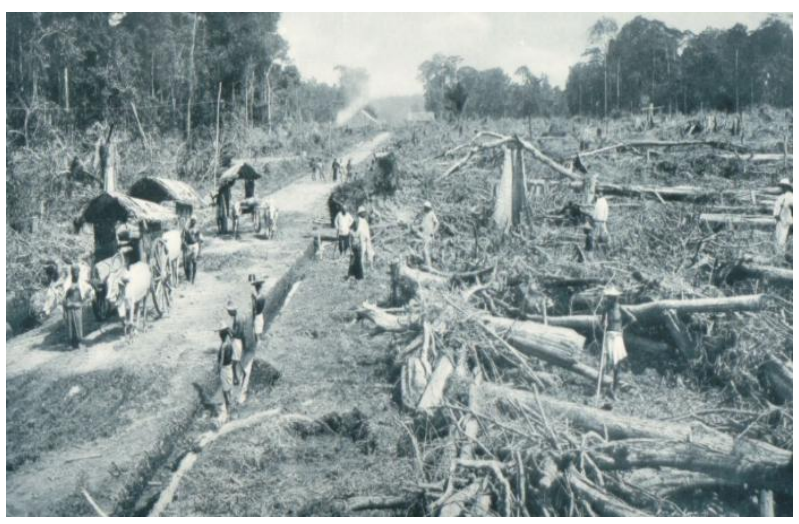

Foto 2. Penebangan hutan untuk membuka perkebunan tembakau di Sumatera Timur tahun 1880-an. Sumber: Digital Collections Leiden University Libraries. Nomor Inv. 80232.

Foto 3 memperlihatkan kuli-kuli India sedang mencangkul tanah untuk membangun kanal. Ukuran kanal yang lebar dan tinggi melebihi ukuran badan merupakan pekerjaan yang sangat membutuhkan tenaga yang besar. Penyakit borok kaki tentu saja menjadi bagian yang tidak terpisahkan dari kehidupan kuli Tamil karena kaki mereka selalu terendam dalam air dan lumpur pada saat bekerja. Bagi tuan kebun, penyakit seperti itu bukan menjadi alasan untuk kuli tidak bekerja. Luka-luka ringan yang di- 
dapat sewaktu bekerja harus diobati sendiri oleh para kuli (Harahap, 2014: 53).

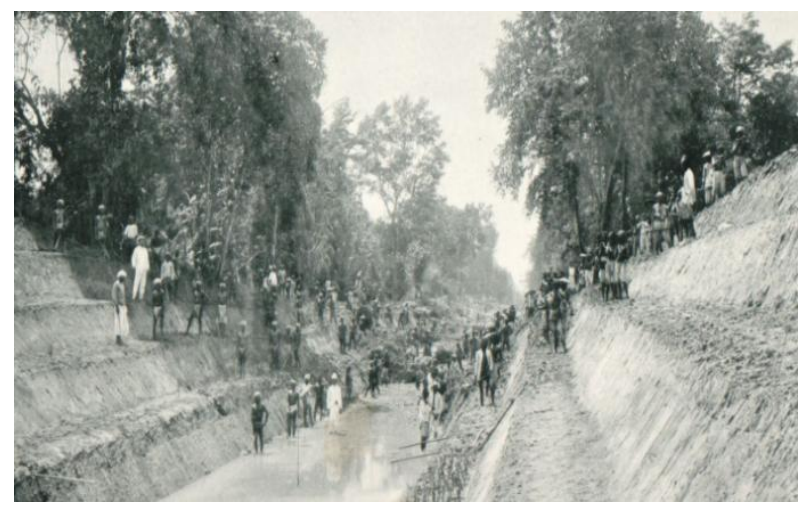

Foto 3. Proses menggali kanal di perkebunan PajaBakong, Sumatera Timur tahun 1898. Sumber: Digital Collections Leiden University Libraries. Nomor Inv. 80229.

Pada konteks yang lain, foto 3 di atas menampilkan sosok seorang staf Eropa yang mengenakan seragam putih dan bertopi putih, sedang berdiri di atas kanal dengan tangan di pinggang sambil mengamati pekerjaan para kuli. Sosok staf Eropa yang ditampilkan foto di atas memberi gambaran tentang sikap pengawasan kerja di perkebunan. Ketika kuli-kuli Tamil sedang bekerja, mereka terus-menerus diawasi oleh asisten Eropa dan tandil (pengawas kuli). Pengawasan itu dilakukan untuk memastikan kuli Tamil bekerja dan menyelesaikan pekerjaan harian sesuai dengan yang telah ditetapkan. Kekerasan fisik terhadap kuli Tamil merupakan tindakan yang kerap dilakukan tandil dan asisten untuk mendisiplinkan kuli yang tidak mematuhi perintah.

Pada masa lumbung sekitar bulan Oktober sampai Januari, kuli Tamil yang bekerja sebagai kusir pedati, hilir mudik di jalan-jalan perkebunan mengangkut hasil panen yang akan diekspor. Pada tahun-tahun awal pembukaan, kulikuli Tamil mengangkut bal-bal tembakau dari lumbung ke sungai yang dapat dicapai oleh sampan-sampan kecil, seperti terekam dalam foto 4 yang diambil tahun 1879 .

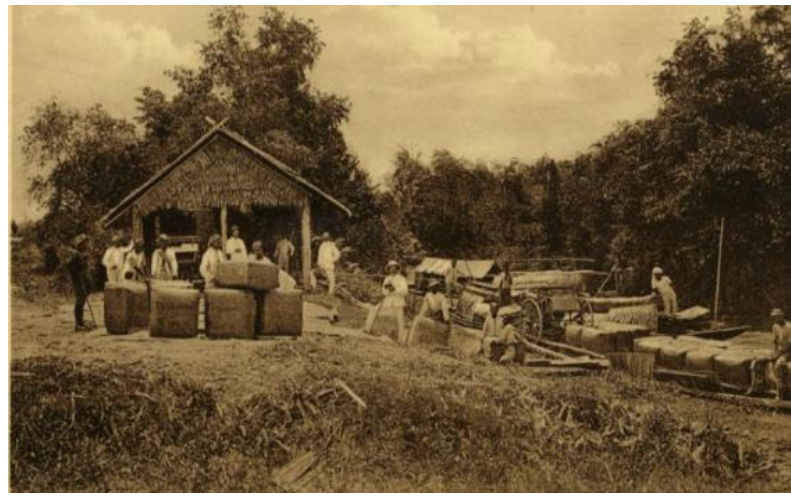

Foto 4. Paket pengiriman tembakau tahun 1879. Sumber: Digital Collections Leiden University Libraries. Nomor Inv. 1402028.

Sungai pada saat itu merupakan jalur utama untuk membawa hasil-hasil panen ke pelabuhan untuk diekspor (Pelzer, 1985: 87). Baru pada tahun 1883, Deli Spoorweg Maatschappij (DSM) mulai membangun jalur kereta api untuk mengangkut hasil panen ke pelabuhan. Sampai akhir dekade pertama abad ke-20, panjang jalur kereta api yang selesai dibangun mencapai kurang lebih 263 kilometer yang menghubungkan pelabuhan Belawan dengan wilayah perkebunan di Deli, Langkat, Serdang, Padang dan Bedagai. Setelah dibukanya jalur kereta api, kuli-kuli Tamil mengangkut bal-bal tembakau dari lumbung ke stasiun-stasiun terdekat, kemudian diangkut menggunakan kereta api ke Belawan untuk diekspor (Harahap, 2014: 56).

Kooeli ordonantie yang dikeluarkan pemerintah Hindia Belanda tahun 1880 menetapkan sepuluh jam kerja sehari (Staatsblad, 1880/2). Namun kenyataannya, kuli Tamil justru bekerja melebihi waktu yang telah ditetapkan koeli ordonantie. Menurut Breman, (1997: 103), kerja lembur dilakukan pada saat istirahat siang, dari pukul sebelas sampai pukul satu siang. Jika sampai pukul enam sore pekerjaan harian yang telah ditetapkan belum selesai dikerjakan, maka kuli tidak diperbolehkan kembali ke bangsal sebelum pekerjaan selesai. Meskipun bekerja lembur, lebih dari sepuluh jam sehari, setiap kuli Tamil hanya menerima 6 sampai 7 dolar per 
bulan. Menurut sumber lain, kuli Tamil yang bekerja membangun jalan dan menggali kanal menerima 20 sen per hari (Broersma, 1919: 281). Jika pekerjaan harian yang telah diperintahkan tidak dilaksanakan dengan sebaikbaiknya, maka upah harian kuli dapat dipotong separuh oleh tuan kebun. Sebagai perbandingan, besarnya upah yang diterima kuli Tamil dalam sebulan tidak jauh berbeda dengan upah kuli laki-laki Jawa yang menerima 6 dolar per bulan. Pembayaran upah dilakukan setiap awal bulan dan pertengahan bulan.

Tidak hanya menerima gaji yang sangat minim, tuan kebun juga kerap memotong sebagian dari upah kuli Tamil untuk melunasi uang panjar yang pernah mereka terima sewaktu dikontrak. Selain pungutan uang panjar, tuan kebun juga menyita sebagian dari upah kuli Tamil untuk membayar harga tikar, bantal, tempat tidur dan peralatan kerja yang mereka terima saat baru tiba di perkebunan. Bahkan biaya obat-obatan dan tempat tinggal juga dipungut dari upah kuli. Berbagai pemotongan itu semakin mengurangi upah kuli Tamil, sehingga untuk membiayai kebutuhan makan sehari-hari saja tidak mencukupi, apalagi untuk keperluan lain. Azwar (2004; 118-119) mengemukakan bahwa untuk dapat membiayai kebutuhan makan di Deli pada tahun 1887, setiap orang harus memperoleh $f 16$ per bulan. Biaya kebutuhan makan itu tentu saja jauh lebih besar daripada upah yang diterima kuli-kuli Tamil. Agar dapat memenuhi kebutuhan hidup seharihari, mereka terpaksa berhutang di kedai-kedai perkebunan. Pada hari gajian, pemilik kedai langsung menagih hutang kepada kuli. Sampai kuli mengakhiri masa kontraknya, kredit "tak terbatas" yang diberikan pemilik kedai tidak dapat dilunasi oleh kuli (Harahap, 2014: 58).

Perjudian merupakan gaya hidup yang sengaja dibuat oleh tuan kebun untuk masyarakat perkebunan di Sumatera Timur. Perjudian yang digelar ketika hari gajian besar (akhir masa lumbung) merupakan cara tuan kebun untuk mendorong kuli menggunakan uang lebih banyak daripada bulan-bulan sebelumnya, dan sebagai perangkap agar kuli terlilit utang sehingga terpaksa menandatangani kontrak baru. Dengan begitu, biaya perekrutan jauh lebih murah dibandingkan dengan biaya merekrut kuli dari daerah asalnya (Breman, 1997: 133). Kemungkinan beberapa kuli Tamil juga terlibat dalam perjudian, meskipun menurut Cremer (1881: 41) kuli Tamil sangat irit, tidak berjudi dan tidak menghisap candu, hanya di kalangan kaum Paria dari waktu ke waktu mabuk.

Kebiasaan mabuk di kalangan kuli Tamil kerap kali terjadi seperti pada tahun 1899, seorang kuli Tamil telah meninggal karena terlalu banyak minum arak dan mayatnya ditemukan di bawah kereta lembu miliknya (De Sumatra Post, 20 Juni 1889). Akibat sering mabukmabukan, kuli Tamil sering dijatuhkan hukuman denda denda maksimal $f 25$ atau kerja paksa untuk pekerjaan umum (krakal) tanpa upah maksimal 12 hari sesuai dengan peraturan koeli ordonantie (Staatsblad, 1880/9). Pada bulan Mei 1891 sebagai contoh, pengadilan telah menjatuhkan hukuman 12 hari krakal terhadap empat kuli Tamil karena mabuk (Deli Courant, 1 Agustus 1891).

Selain orang Tamil, para pengusaha perkebunan juga mempekerjakan orang Sikh yang berasal dari Punjab, India Utara. Para tuan kebun menyebut orang Sikh dengan sebutan Bengaleezen atau orang Benggali. Tuan kebun memperkerjakan orang Sikh sebagai opas perkebunan, karena kebanyakan dari mereka adalah mantan serdadu militer dan polisi di Straits Settlements sehingga layak dijadikan sebagai penjaga keamanan. Menurut Mani (1993: 85), orang Sikh bermigrasi ke Sumatera Timur atas kemauan sendiri untuk bekerja sebagai opas perkebunan. Ketika jumlah migran Sikh di Straits terus meningkat sejak pertengahan abad ke-19, banyak di antara mereka yang bekerja sebagai peternak sapi, penjual susu, kusir pedati dan penjaga keamanan (Mani, 2011: 17-42). Selain menduduki pekerjaan tersebut, orang Sikh memiliki sumber penghasilan lain, yaitu sebagai 
pemberi pinjaman uang kepada kuli dengan imbalan bunga.

Kedudukan ekonomi orang Sikh lebih beruntung dibandingkan dengan kuli Tamil apabila dilihat dari jumlah penghasilan yang mereka dapatkan. Sebagai opas perkebunan, orang Sikh menerima upah 115 dolar per tahun, jauh lebih besar dari upah para kuli Tamil.

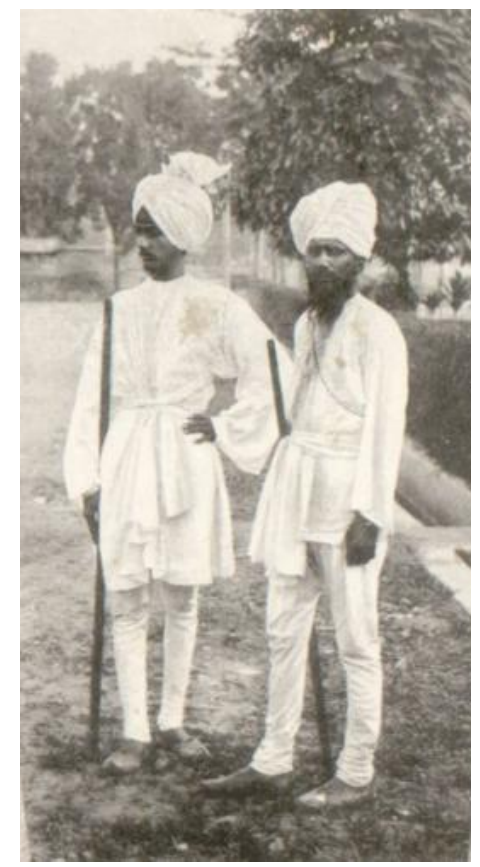

Foto 5. Orang Benggali sebagai opas perkebunan di Sumatera Timur tahun 1879. Sumber: Digital Collections Leiden University Libraries. Nomor Inv. 80263.

Foto 5 di atas secara jelas menggambarkan penampilan orang Sikh yang bekerja sebagai penjaga di salah satu perkebunanan tembakau pada akhir abad ke-19. Orang Sikh lebih disukai oleh tuan kebun untuk menjaga keamanan perkebunan karena mereka pernah belajar menembak saat menjadi serdadu militer dan polisi di Straits Settlements, dan kemampuan itu bermanfaat pada saat terjadi kerusuhan di perkebunan. Terlihat dari foto di atas orang Sikh sedang memegang sebuah tombak yang terbuat dari besi untuk melakukan proses pengamanan ketika terjadi kerusuan di perkebunan. Dari berbagai berita di surat kabar terungkap bahwa di perkebunan tembakau Deli terjadi banyak kasus pemberontakan dan serangan terhadap tuan kebun akibat dari penerapan koeli ordonantie dan poenale sanctie yang menyengsarakan para kuli.

Dari foto 5 terlihat juga penampilan fisik laki-laki Sikh yang sedang menggunakan pakaian putih dan celana panjang putih, lengkap dengan turban (ikat kepala) dan memelihara jenggot. Biasanya lelaki India mengenakan dhoti dengan kaos putih, dan ada pula yang memakai sarung dan menutupi badannya dengan selempang kain. Penampilan laki-laki India yang mengenakan pakaian dhoti dalam kehidupan seharihari dapat dilihat pada foto 6 di bawah ini.

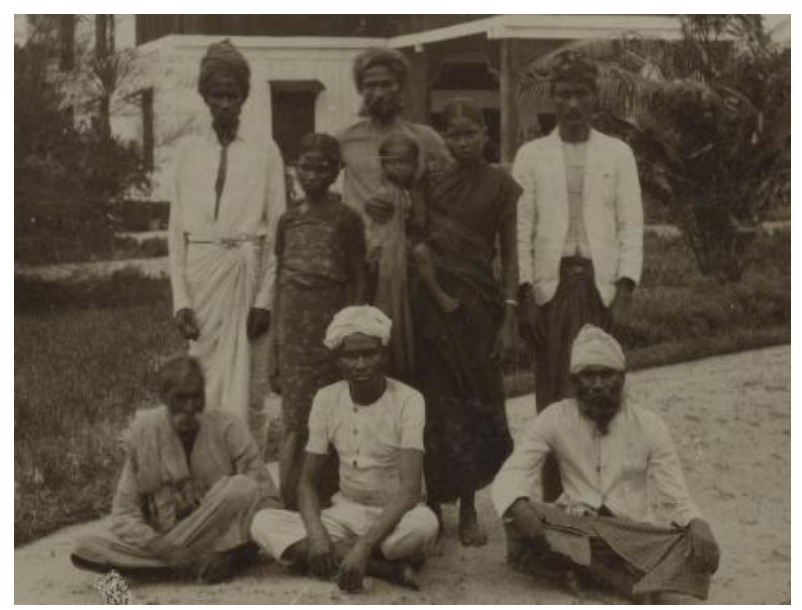

Foto 6. Kuli India di perkebunan tembakau Tandjong Kasan Estate Asahan tahun 1894. Sumber: Digital Collections Leiden University Libraries. Nomor Inv. 90634.

Foto 6 di atas menunjukan dua perempuan Tamil, yang satu perempuan dewasa sedang menggendong anak kecil dan satu lagi anak perempuan yang masih remaja. Terlihat salah satu di antara perempuan India menggunaka pakaian saree dengan memakai aksesor gelang kaki.

Penampilan wanita Tamil secara jelas ditampilkan dalam foto 7 . Wanita Tamil dalam foto tersebut terlihat anggun, badannya tinggi 
dan agung. Selendang panjang melilit leher melalui depan dada, dililitkan atau diikat di pinggang supaya selendang tidak terlepas. Badannya yang agung dan tatapan yang tajam mencermikan model foto masa lalu. Di hidungnya tampak berkilat kancing emas. Singkatnya, penampilannya mencerminkan gaya hidup India dengan dilengkapi asesoris perhiasan kalung dan gelang yang besar serta di kakinya terdapat juga gelang kaki emas. Dari gambar tersebut menunjukkan bahwa perempuan Tamil dalam kehidupan sehari-hari masih mempertahankan identitas budayanya.

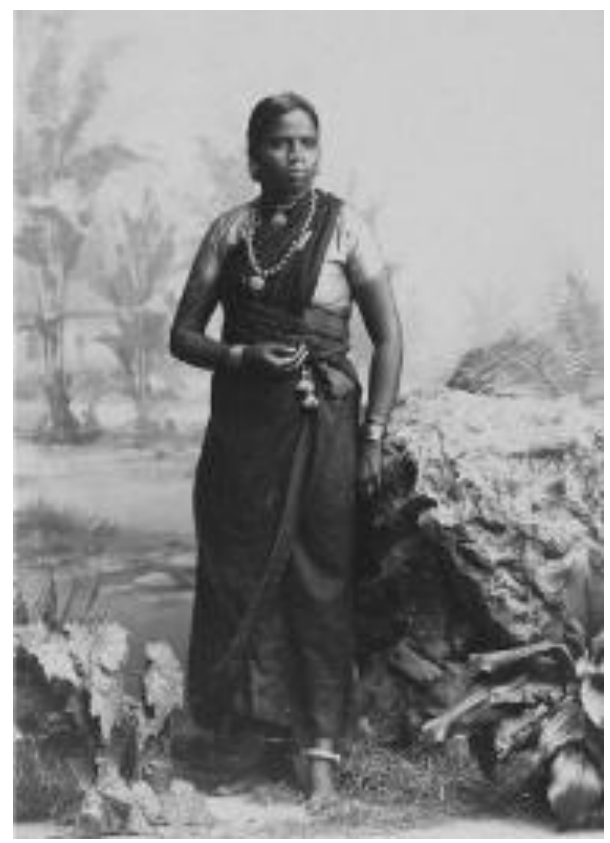

Gambar 7. Perempuan Tamil di Medan tahun 1900. Sumber: Digital Collections Leiden University Libraries. Nomor Inv. 2613.

Dalam kehidupan masyarakat perkebunan di Sumatera Timur, pemisahan berdasarkan suku bangsa tidak hanya tampak dari pembagian kerja, melainkan juga melalui pemukiman (Harahap, 2014: 61). Kuli-kuli India ditempatkan dalam satu kompleks pemukiman terpisah dengan bangsal kuli Cina dan kuli Jawa. Bangsal-bangsal kuli dibangun berderet di sisi jalan atau berupa bujur sangkar mengelilingi lapangan. Bangsal-bangsal itu berlantaikan tanah, berdinding papan dan beratap daun nipah, dengan sedikit jendela. Di dalam bangsal hanya ada tempat tidur yang juga digunakan sebagai meja makan. Ruangan bangsal yang pengap, ditambah dengan sisa sampah dan air yang tergenang menambah bau dan kotornya pemukiman para kuli yang menjadi sumber penyakit bagi penghuninya (Breman, 1997: 121). Di sekitar bangsal terdapat kandang sapi, gudang peralatan, dan candi untuk kuli Tamil beribadah (Cate, 1905). Foto 8 memperlihatkan kuli-kuli Tamil sedang berdiri di belakang bangsal mereka. Foto ini diambil pada tahun 1898-1905.

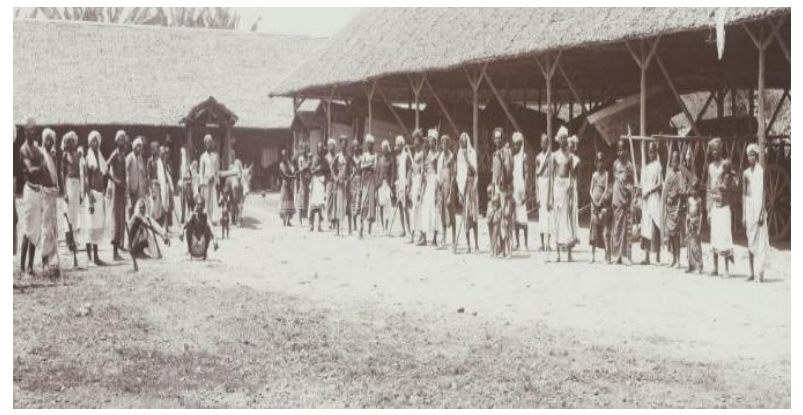

Gambar 8. Kuli-kuli Tamil dengan gerobak-gerobak sapi di salah satu perkebunan tembakau Sumatera Timur tahun 1898. Sumber: Digital Collections Leiden University Libraries. Nomor Inv. 35767.

Foto 8 di atas memperlihatkan bahwa bangsal kuli Tamil dilengkapi dengan tempat penyimpanan gerobak sapi pengangkut tembakau. Foto tersebut juga memperlihatkan beberapa perempuan dewasa dan anak-anak. Hal ini membuktikan bahwa sebagian kuli Tamil yang dipekerjakan di perkebunan tembakau Deli memiliki keluarga. Menurut Mani (1993: 57), kuli laki-laki Tamil yang masih bujangan dapat memperoleh seorang istri dari tenaga kerja baru yang dibawa kangany ke perkebunan, itupun jika mereka membayar sejumlah uang kepada $k a-$ ngany.

Akibat dari eksploitasi kerja, kemiskinan, diskriminasi dan penderitaan yang terus-menerus dialami para pekerja kontrak di perkebunan, 
banyak kuli-kuli Tamil yang sudah habis masa kontraknya dan tidak terlilit utang pada tuan kebun maupun tandil sedapat mungkin mencari kehidupan baru di tempat lain. Salah satu tujuan mereka di penghujung akhir abad ke-19 adalah kota Medan yang merupakan pusat aktivitas perdagangan dan administrasi di Sumatera Timur.

\section{SIMPULAN}

Foto-foto koleksi Digital Collections Leiden University Libraries menunjukkan berbagai realitas kehidupan orang India di perkebunan tembakau Deli dari tahun 1872 sampai 1900. Foto-foto itu menggambarkan hal-hal yang menarik tentang sejarah sosial orang India, terutama ketika melakukan kegiatan sehari-hari seperti bekerja. Dalam melakoni sebuah pekerjaan tentunya mereka mendapatkan upah, meskipun tidak sebanding dengan biaya hidupnya. Diferensiasi pekerjaan dan pemukiman berdaskan ras menjadi bagian kehidupan sehari-hari yang dialami orang India di perkebunan tembakau Deli. Seperti kuli Tamil bekerja pada sektor pembangunan jalan, penggalian kanal dan kusir gerobak sapi (pedati). Berbeda dengan orang Tamil, orang Sikh yang diidentifikasi sebagai "orang Benggali” bekerja sebagai opsir atau penjaga keamanan di lingkungan perkebunan dan kantor-kantor perusahaan perkebunan.

Selama bekerja sehari-hari di perkebunan tembakau Deli, orang India mengenakan gaya pakaian asli dari India. Hal yang sama terjadi pada kuli Jawa dan Cina. Melalui pakaian inilah mereka secara sengaja dibedakan berdasar suku bangsa. Tidak hanya itu, pembedaan juga diterima orang India dalam hal tempat pemukiman. Pemukiman kuli India terpisah dengan dengan bangsal kuli Cina dan kuli Jawa.

Periode 1872-1900 merupakan masa orang India menjadi masyarakat perkebunan tembakau Deli. Meskipun penderitaan dan kesengsaraan yang mereka terima, namun ada sisi keberuntungan dan peluang ekonomi yang menjanjikan ketika mereka menjadi kuli dalam kontrol perusahaan perkebunan tembakau di Sumatera Timur.

Foto-foto yang ditersimpan dalam website Digital Collections Leiden University Libraries menggambarkan bahwa orang India sudah menjadi masyarakat perkebunan tembakau Deli pada akhir abad ke-19. Realitas sekarang orang India berada di Sumatera Utara dan menjalani beragam aktivitas ekonomi. Melalui narasi foto kita dapat memahami bagaimana realitas masa lalu orang-orang India yang merupakan orang yang terpinggirkan dalam sejarah Indonesia.

\section{REFERENSI}

Azwar, K. D. (2004). Poenale Sanctie: Studi Tentang Globalisasi Ekonomi dan Perubahan Hukum di Sumatera Timur 1870-1950. Universitas Sumatera Utara.

Blink, H. (1918). Sumatra's Oostkust in hare opkomst en ontwikkeling als economisch gewest: Eene economisch-geographische en -historische studies. Tijdschrift voor Economische Geografie.

Breman, J. (1997). Menjinakkan Sang Kuli; Politik Kolonial, Tuan Kebun dan Kuli di Sumatra Timur pada Awal Abad ke-20. Jakarta: PT. Pusataka Utama Grafis.

Broersma, R. (1919). Ooskust van Sumatra (Eerste). Batavia: Javasche Boekhandel \& Drukkerij.

Cate, A. W. N. Ten. (1905). Deli in Woord en Beeld. Amsterdam: De Bussy.

Coedes, G. (2010). Asia Tenggara Masa HinduBudha. Jakarta: Kepustakaan Populer Gramedia.

Cremer, J. T. (1881). De toekomst van Deli. Leiden : Gualth Kolff.

Cremer, J. T. (1885). Emigratie van Hindu's naar Sumatra. Tijdschrift voor Nederlandsch-Indië. I.

De Sumatra Post, 20 Juni 1889.

Deli Courant, 1 Augustus 1891.

Digital Collections Leiden University Libraries. Retrieved 11 ${ }^{\text {th }}$ April 2019 from https: //digitalcollections.universiteitleiden.nl. 
Harahap, A. (2014). Voor indiërs: Sejarah Kehidupan Sehari-hari Orang India di Kota Medan Abad ke-20. Universitas Gadjah Mada.

Indradjaja, A. (2014). Awal Pengaruh Hindu Buddha Di Nusantara. Kalpataru: Majalah Arkeologi, 3(1), 17-34. https://doi.org/10.24832/kpt.v23i1.48

Lekkerkerker, C. (1916). Land en volk van Sumatra. Leiden: N.V. Boekhandel en Drukkerij Voorheen E.J. Brill.

Lubis, Z. B. (2005). Kajian Awal Tentang Komunitas Tamil dan Punjabi di Medan: Adaptasi dan Jaringan Sosial. ETNOVISI: Jurnal Antropologi Sosial Budaya, 1(3), 136-146.

Mani, A. (1993). Indian in North Sumatra. In K. S. Sandhu \& A. Mani (Ed.), Indian Communities in Southeast Asia (pp. 4697). Singapore: ISEAS.

Mani, A. (2011). Sikh in Multi-ethnic Indonesia. In Samsul A. B. \& Arunajeet Kaur (Ed.), Sikh in Southeast Asia: Negotiating an Identity (pp. 17-42). Singapore: ISEAS.

McKinnon, E. E. (1984). Kota Cina; Its Context and Meaning in the Trade of Southeast Asia in the Twelfth to Fourteenth Centuries. Cornell University.

Pelzer, K. J. (1985). Toean Keboen dan Petani: Politik Kolonial dan Perjuangan Agraria di Sumatra Timur 1863-1947. Jakarta: Sinar Harapan.

Sinar, T. L. (2006). Bangun Runtuhnya Kerajaan Sumatera Timur. Medan: Yayasan Kesultanan Serdang.

Sinar, T. L. (2008). Orang India di Sumatera Utara. Medan: Forkala Sumut.

Staatsblad van Nederlandsch-Indië, No. 133 (1880).
Stoler, A. L. (2005). Kapitalisme dan Konfrontasi di Sabuk Perkebunan Sumatra, 1870-1979. Yogyakarta: Karsa. Taylor, J. G. (2008). Aceh: Narasi Foto, 18731930. In H. S. Nordholt, et.al. (Ed.), Perspektif Baru Penulisan Sejarah Indonesia (pp. 313-372). Jakarta: Yayasan Obor Indonesia.

Utomo, B. B. (2016). Orang Tamil di Tanah Andalas di Masa Lampau. In I. Azhari (Ed.), 80 Tahun Arkeolog Dr. Edmund Edwards McKinnon: Perintis Riset Kota China sebagai Situs Internasional di Medan (pp. 35-60). Medan: Unimed Press. 